\title{
Pure sensory ganglionopathy as the first sign of relapse in non-Hodgkin lymphoma
}

\section{Figure $\quad$ MRI lumbar spine with contrast and ${ }^{18}$ FDG-PET}

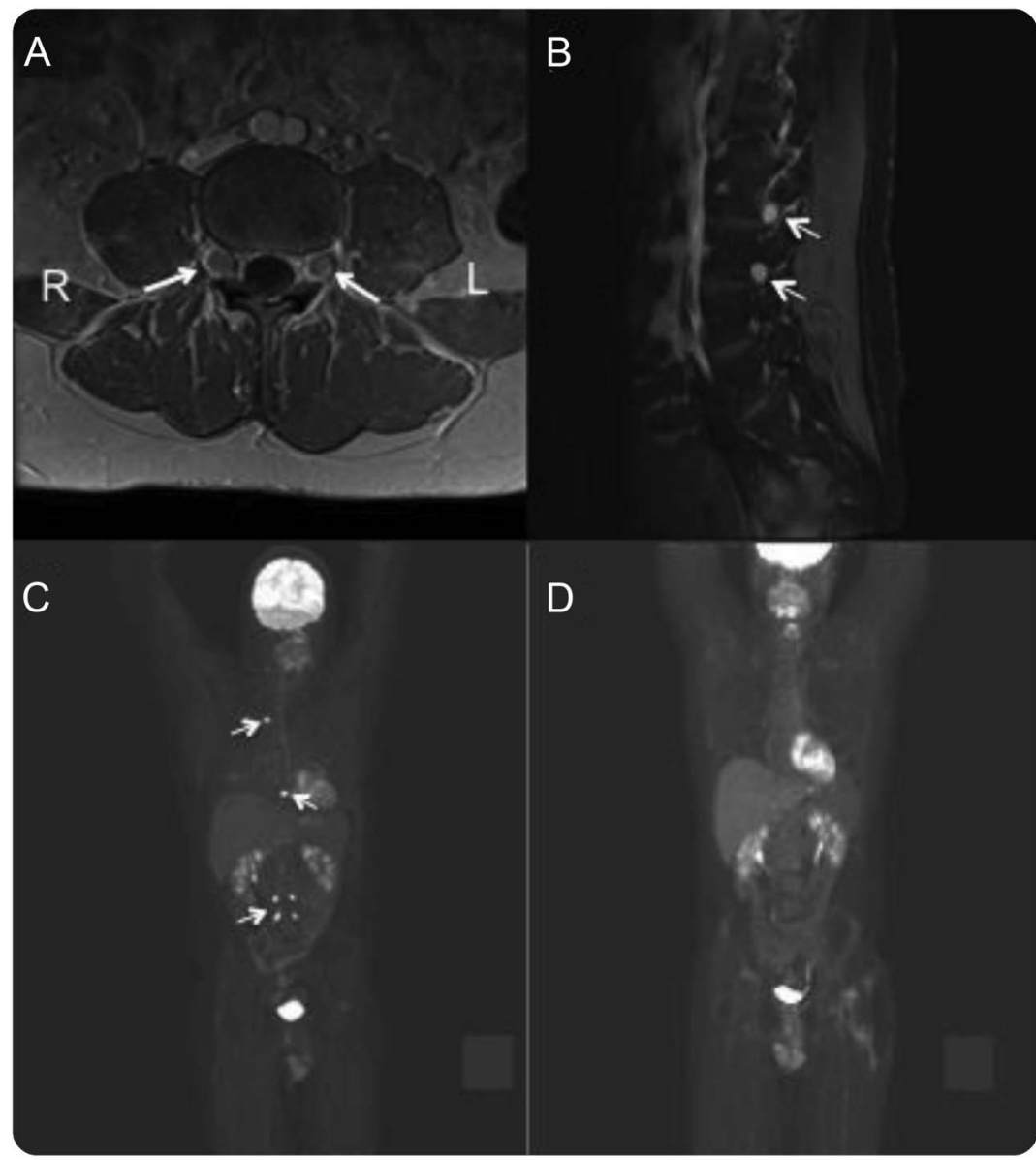

Enlarged and enhancing dorsal root ganglia at L3, L4 in (A) axial and (B) sagittal views. FDG uptake at T2, T8, and L3-L4 dorsal root ganglia (C) before and (D) after radiation therapy.

A 34-year-old man with diffuse large B-cell lymphoma in complete remission presented with painful paresthesias of the thorax and proximal legs with loss of patellar reflexes bilaterally. Laboratory studies showed no evidence of autoimmune or infectious processes. CSF cytology was unremarkable. MRI showed enlarged, enhancing dorsal root ganglia (DRG) at L3-L4 bilaterally (figure, A). Whole-body PET showed avidity in these nerve roots and in T2 and T8 (figure, C). Abnormalities on nerve conduction studies were isolated to sensory nerves affecting the same roots. Sensory ganglionopathies can occur with lymphomatous infiltration of the DRG, known as neurolymphomatosis, and can be the initial manifestation of lymphoma relapse. ${ }^{1,2}$

Michael Hossack, MD, * Jeffrey McClean, MD*

*These authors contributed equally to this work.

From the 59th Medical Wing, San Antonio Military Medical Center, TX.

Author contributions: Michael Hossack: title, interpretation of data, writing of manuscript. Jeffrey McClean: performed/interpreted NCS/EMG, critical revision of manuscript.

Study funding: No targeted funding reported. 
Disclosure: The authors report no disclosures relevant to the manuscript. Go to Neurology.org for full disclosures.

Correspondence to Dr. Hossack: mrh8gcat@gmail.com

1. Tomita M, Koike H. Clinicopathological features of neuropathy associated with lymphoma. Brain 2013;136:2563-2578.

2. Graus F, Helena A, Josep D. Paraneoplastic neurological syndromes in Hodgkin and non-Hodgkin lymphomas. Blood 2014; 123:3230-3238.

\section{WriteClick ${ }^{\circledR}$ rapid online correspondence}

The editors encourage comments about recent articles through WriteClick:

Go to Neurology.org and click on the "WriteClick" tab at the top of the page. Responses will be posted within 72 hours of submission.

Before using WriteClick, remember the following:

- WriteClick is restricted to comments about studies published in Neurology within the last eight weeks

- Read previously posted comments; redundant comments will not be posted

- Your submission must be 200 words or less and have a maximum of five references; reference one must be the article on which you are commenting

- You can include a maximum of five authors (including yourself)

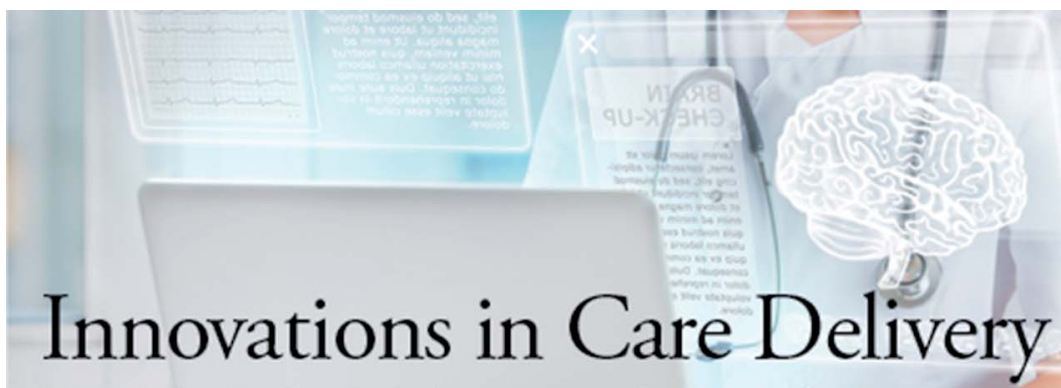

A curated collection featuring advances in neurologic care

NEW!

\section{Innovations in Care Delivery - A curated collection featuring advances in neurologic care}

This $N$ eurology ${ }^{\circledR}$ special interest website provides a forum to explore new care models from multiple disciplines, access to sources on health care innovation, and expert opinions on current research from Neurology journals. Curated by Brian C. Callaghan, MD, and Kevin A. Kerber, MD.

Stay ahead of the curve at Neurology.org/innovations. 


\section{Neurology}

\section{Pure sensory ganglionopathy as the first sign of relapse in non-Hodgkin lymphoma Michael Hossack and Jeffrey McClean}

Neurology 2017;88;1976-1977

DOI 10.1212/WNL.0000000000003943

\section{This information is current as of May 15, 2017}

Updated Information \&
Services

References

Subspecialty Collections

Permissions \& Licensing

Reprints including high resolution figures, can be found at: http://n.neurology.org/content/88/20/1976.full

This article cites 2 articles, 1 of which you can access for free at: http://n.neurology.org/content/88/20/1976.full\#ref-list-1

This article, along with others on similar topics, appears in the following collection(s):

All Clinical Neurology

http://n.neurology.org/cgi/collection/all_clinical_neurology All clinical neurophysiology

http://n.neurology.org/cgi/collection/all_clinical_neurophysiology

All Imaging

http://n.neurology.org/cgi/collection/all_imaging

All Oncology

http://n.neurology.org/cgi/collection/all_oncology

Information about reproducing this article in parts (figures,tables) or in its entirety can be found online at:

http://www.neurology.org/about/about_the_journal\#permissions

Information about ordering reprints can be found online:

http://n.neurology.org/subscribers/advertise

Neurology ${ }^{\circledR}$ is the official journal of the American Academy of Neurology. Published continuously since 1951, it is now a weekly with 48 issues per year. Copyright () 2017 American Academy of Neurology. All rights reserved. Print ISSN: 0028-3878. Online ISSN: 1526-632X.

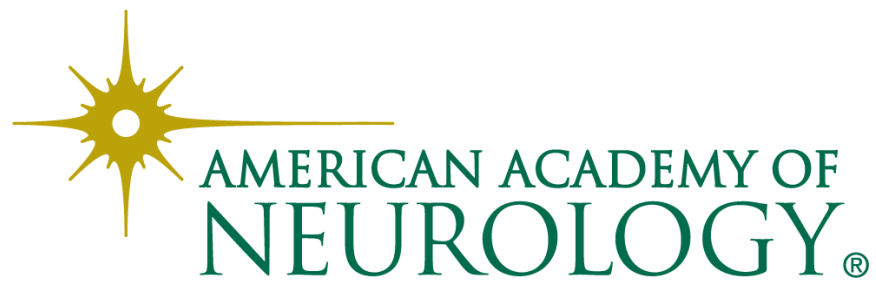

